\title{
Establishing a neotype for Crocidura obtusa Kretzoi, 1938 (Mammalia, Soricidae): an emended description of this Pleistocene white-toothed shrew species
}

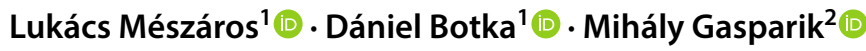

Received: 31 May 2018 / Accepted: 26 May 2019 / Published online: 18 June 2019

(c) The Author(s) 2019

\begin{abstract}
We establish a neotype in the collection of the Hungarian Natural History Museum, Budapest (Hungary) for Crocidura obtusa (Mammalia, Soricidae). The species was originally described by M. Kretzoi as a new species from the Early Pleistocene locality of Gombaszög (now Gombasek, Slovakia) in 1938, but the holotype was lost in 1956. The neotype is a complete left mandible from the Osztramos 8 site (Hungary, Early Pleistocene). Due to the incomplete original description given by Kretzoi, a new definition of this species also had to be composed. Kretzoi's distinctive characteristics between C. obtusa and the recent Crocidura species are accepted here, but further differences were discovered in comparison with the contemporary C. kornfeldi. According to our taxonomic results, C. obtusa was present in Central Europe, mainly in the Carpathian Basin, from the Early Pleistocene (ca. 1.2 Ma) to the earliest Late Pleistocene (ca. 130-115 ka).
\end{abstract}

Keywords Crocidura obtusa $\cdot$ Early Pleistocene $\cdot$ Lost holotype $\cdot$ Neotype $\cdot$ Soricidae

\section{Introduction}

Crocidura obtusa was described by Kretzoi (1938) from the Early Pleistocene locality of Gombaszög (now Gombasek, Slovakia). To date, the species has been reported from several sites in Central Europe (Fig. 1), and these occurrences delineate a stratigraphic range from the Early Pleistocene (ca. 1.2 Ma) to the earliest Late Pleistocene (ca. 130-115 ka) (Botka and Mészáros 2015).

As the original diagnosis given by Kretzoi (1938) was not detailed enough, the classification of these forms was made on the basis of teeth measurements. Botka and Mészáros (2015) elaborated a rich Crocidura material from the late Early Pleistocene Somssich Hill 2 locality (Hungary). Their morphometric studies revealed that differentiation of

\section{Handling Editor: Irina Ruf.}

Mihály Gasparik

gasparik.mihaly@nhmus.hu

1 Department of Palaeontology, Eötvös Loránd University, Pázmány Péter sétány 1/C, Budapest 1117, Hungary

2 Department of Palaeontology and Geology, Hungarian Natural History Museum, Ludovika tér 2-6, Budapest 1083, Hungary isolated teeth of $C$. kornfeldi and C. obtusa is not realistic on the basis of measurements only. They emended the original diagnosis according to the observations of Rzebik-Kowalska (2000: fig. 13B) and their studies on the Somssich Hill 2 material with some morphological characters. The taxonomic difficulties caused by the incomplete original diagnosis are enhanced by the fact that the type material was not available for morphological study.

Designating a neotype for $C$. obtusa Kretzoi, 1938 was necessary because the original holotype described by Kretzoi in 1938 has been lost, and it was just a single specimen without any paratypes or any other kind of type specimens.

\section{Historical background}

The original holotype was deposited and marked with inventory number HNHM Fa. 16. in the Department of Palaeontology and Geology of the Hungarian Natural History Museum (at that time, part of the Hungarian National Museum). This specimen is mentioned as missing in the department's type catalogue from 2008 (Pálfy et al. 2008). In another earlier type catalogue (Boda 1964), the specimen is not even mentioned. It must thus be supposed that the holotype was lost before the $1960 \mathrm{~s}$, because it is missing from 


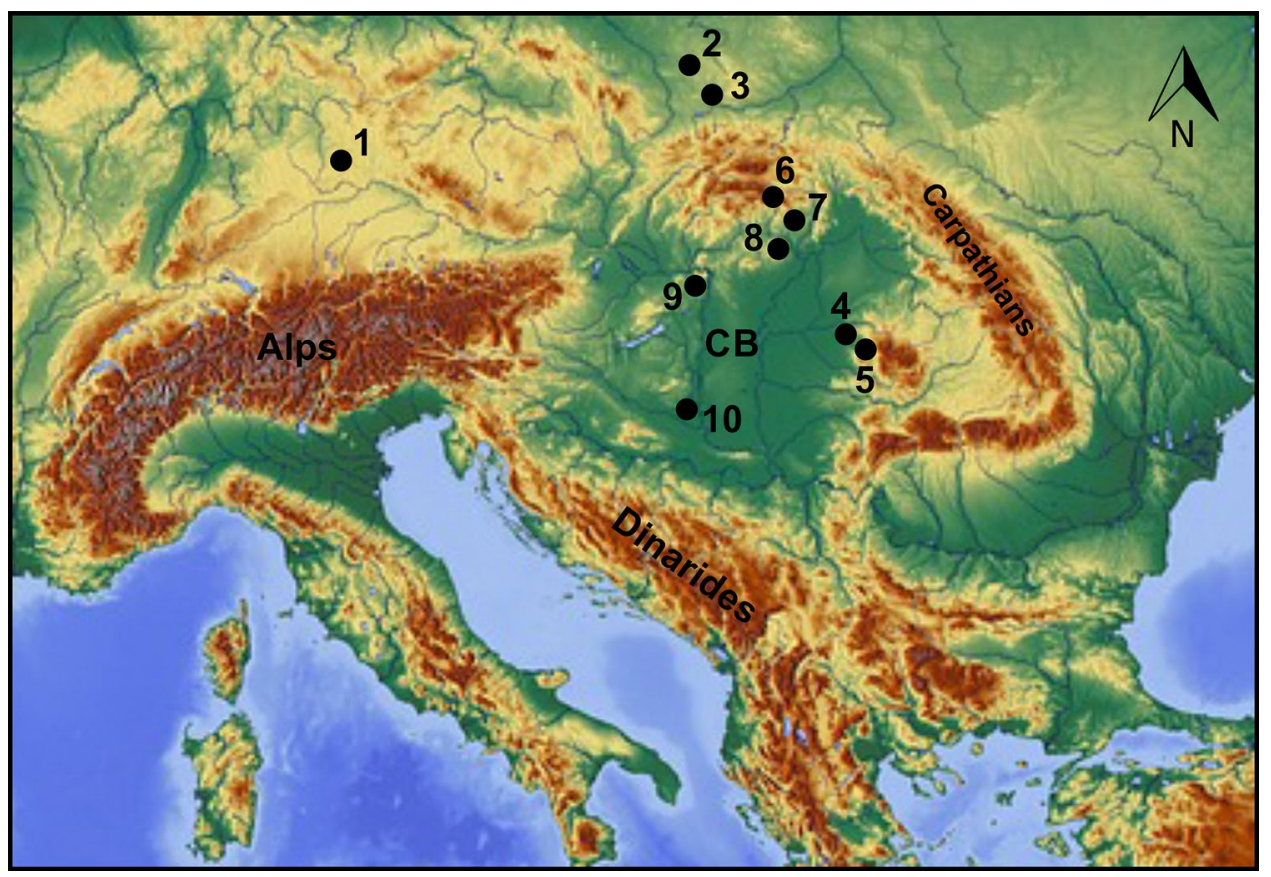

Fig. 1 Pleistocene Crocidura obtusa occurrences on mainland Europe. 1-Weißenburg 7, Germany, Early Pleistocene (von Koenigswald 1971); 2-Przymiłowice 2B, Poland, Early Pleistocene (cf., Rzebik-Kowalska 2013); 3-Biśnik Cave VI, VIII, IX, Poland, Middle to Late Pleistocene (Stefaniak et al. 2009); 4-Betfia IX, Romania, Early Pleistocene (cf., Rzebik-Kowalska 2000, 2002); 5-Urşilor Cave, Romania, Early Pleistocene (cf., Rzebik-Kowalska 2002); 6Gombasek, Slovakia, Early Pleistocene (Kretzoi 1938, 1941; Wagner and Gasparik 2014); 7-Osztramos 8 and 14, Hungary, Early Pleistocene (aff., Jánossy and Kordos 1977); 8-Pongor Cave (Pazonyi

these catalogues, and some later authors (Jánossy 1962, 1969a, b; von Koenigswald 1971) cited only the original description of the holotype of $C$. obtusa but did not refer to the type specimen itself.

The collections of the Hungarian Natural History Museum were severely damaged twice between 1938 and 1960: in World War II and later during the Hungarian Revolution (October 1956). The department, housed in the Hungarian National Museum's building at that time, was destroyed by fire in both cases (Gasparik 2007; Papp 2016). The latter incident was much more tragic for the Department of Palaeontology and Geology, with almost $75 \%$ of the collection being ruined. Hence, very probably, the type specimen of $C$. obtusa was also lost at that time.

Unfortunately, we can preclude the possibility that the specimen has been lent, because no loans of type specimens are allowed by the rules of the museum, and this is confirmed by the archive data of the department, where no loan of $C$. obtusa is registered. Because Kretzoi worked in the Hungarian Geological Institute, it could be supposed that he borrowed the specimen from the museum for his work. However, we can also exclude this, because a detailed
2011), Kövesvárad (cf., Jánossy 1986), and Tarkő 1, 4, 9-14, Hungary, Middle Pleistocene (cf., Jánossy 1969a, b, 1986); 9-Újlak Hill, Budapest, Early Pleistocene (Jánossy 1986), Castle Hill, Budapest, (cf., Jánossy 1986), and Ördöglyuk Cave, Hungary, Middle Pleistocene (Pazonyi 2011); 10-Somssich Hill 2 (Botka and Mészáros 2015), and Beremend 16, Early Pleistocene (Jánossy 1996), Villány 6 (Jánossy 1986), and Nagyharsányhegy 4 (Kretzoi 1956), Hungary, Middle Pleistocene; CB-Carpathian Basin. A table with an overview of the species can be found in Botka and Mészáros (2015)

revision has been carried out of the collection and registry of both the Department of Palaeontology and Geology of the Hungarian Natural History Museum and the Palaeontological Collection of the Hungarian Geological Institute in the last few years, which did not reveal the type specimen of C. obtusa. After his death in 2005 , a considerable collection of papers, reprints, and fossils was donated to the Hungarian Natural History Museum from the bequest of Kretzoi, containing some earlier inventoried specimens, but not the C. obtusa type specimen. In conclusion, we have to state that the type specimen had been lost and, indeed, very probably destroyed.

During the establishment of the neotype, first, with kind assistance from Jan Wagner, we tried to find a new type specimen from the same locality, i.e., Gombasek (Gombaszög), but were not able to find an appropriate $C$. obtusa specimen, in either earlier or later collected materials stored in different collections in Hungary, Slovakia, and the Czech Republic.

After the studies of Kretzoi (1938, 1941), further excavations were carried out at the Gombasek locality, the material of which represents different stratigraphic levels (Wagner 
and Gasparik 2014). Unfortunately, if any specimens of Crocidura were yielded by those explorations, they will not certainly be from exactly the same niveau as Kretzoi's type specimen.

The required differential characteristics were well identified on the specimens from the Somssich Hill 2 locality (Botka and Mészáros 2015), but the remains were not complete enough to define them as a neotype. A complete specimen of $C$. obtusa was found in the records of the Osztramos 8 locality (Jánossy 1969a, b). It is a well-preserved complete mandible showing all characteristics described on the original holotype, and its age roughly fits with the old Gombasek material. Although the time difference between the two sites could be ca. $0.5 \mathrm{Ma}$, these occurrences are included in the stratigraphic range of $C$. obtusa reported by authors from several localities in Europe. The two localities are closely situated geographically, thus meeting the criteria for designation of a neotype.

\section{Materials and methods}

The neotype specimen is inventoried in the Department of Palaeontology and Geology of the Hungarian Natural History Museum, Budapest (inventory number: HNHM V.73.93.). Further mandibles from Somssich Hill 2, Beremend 16/9, Osztramos 8, and Tarkő sites, stored in the same collection, were also used in the morphometric analysis (see the captions of Fig. 4).

Morphological terms are used after Reumer (1984). No scanning electron microscopy (SEM) images of the neotype specimen could be taken because it was covered with a special lacquer during the former conservation procedure. Therefore, the investigation was carried out with a Delta Smart 5MP Pro digital USB microscope, using Delta Optical Smart Analysis Pro 1.0.0 software for measurements (given in $\mathrm{mm}$ ). Morphometric analysis was carried out with the help of MS Excel software, using which three scatter plots were drawn for each molar ( $\mathrm{m} 1, \mathrm{~m} 2$, and $\mathrm{m} 3)$.

Abbreviations. $\mathrm{HNHM}=$ Hungarian Natural History Museum, $\mathrm{i}=$ incisor, $\mathrm{a}=$ antemolar, $\mathrm{m}=$ molar, $\mathrm{p}=$ premolar, $\mathrm{L}=$ length, $\mathrm{W}=$ width, $\mathrm{H}=$ height, inv. $\mathrm{n} .=$ inventory number.

\section{Systematic paleontology}

Class Mammalia Linnaeus, 1758

Order Eulipotyphla Waddell, Okada and Hasegawa, 1999

Family Soricidae Fischer von Waldheim, 1814

Subfamily Crocidurinae Milne-Edwards, 1874
Genus Crocidura Wagler, 1832

Crocidura obtusa Kretzoi, 1938

Figure 2

*1938 C. obtusa n. sp.—Kretzoi: p. 92, fig. 1a [original description].

2000 Crocidura cf. obtusa Kretzoi, 1938-Rzebik-Kowalska: p. 39, figs. 13B and 14 [detailed description].

v 2015 C. obtusa Kretzoi, 1938-Botka and Mészáros: p. 72, figs. 3 and 4 [emended diagnosis].

Holotype. The holotype described by Kretzoi (1938) was a right mandible, but it was lost from the collection of the Hungarian Natural History Museum (Pálfy et al. 2008: p. 140). The original inventory number was HNHM Fa. 16.

Original type locality. Gombasek (Gombaszög), Slovakia, Early Pleistocene.

Original diagnosis. Kretzoi (1938) distinguished C. obtusa sp. nov. from $C$. leucodon based on its shorter a1 and less pointed a2 in his German description: "Dimensionell stimmen sie mit Crocidura leucodon gut überein, welcher Art sie auch morphologisch am nächsten stehen. Doch weichen sie von dieser im mehr in die Länge ausgezogenen C. inf. und stumpferen $\mathrm{P}^{4}$ gut ab." He demonstrated this distinction also by $C$. russula on a figure drawn for his article (Kretzoi 1938, figs. 1a-c). In the drawing, it can be clearly identified that $\mathrm{C}$ inf. $=\mathrm{a} 1$ and $\mathrm{P} 4=\mathrm{a} 2$. Unfortunately, he did not measure the teeth. He also missed listing any true differences between the new species and the contemporary fossil Crocidura shrews. ("Die aus dem ungarischen Altquartaer beschriebenen ... Crocidura-Arten ... kommen hier ... nicht ... in Betracht.").

Neotype (established by the authors herein). Left mandible with complete dentition (HNHM V.73.93.).

New type locality. Osztramos 8 locality, Early Pleistocene, ca. 1.2 Ma (Jánossy and Kordos 1977).

New diagnosis. Crocidura obtusa Kretzoi, 1938 is different from the contemporary C. kornfeldi Kormos, 1934, having higher ramus mandibulae, distinct coronoid spicule, tip of the coronoid process leaning more backwards, higher condyle, and longer interarticular area (Fig. 3). It can be distinguished from the Early Pleistocene Crocidura zorzii Pasa, 1942 by its smaller dimensions. It differs from the recent C. leucodon (Hermann, 1780), C. russula (Hermann, 1780), 
Fig. 2 Crocidura obtusa Kretzoi, 1938, neotype from Osztramos 8 locality, left mandible with complete dentition (HNHM V.73.93.), buccal view (above) and lingual view (below). Scale bar $1 \mathrm{~mm}$
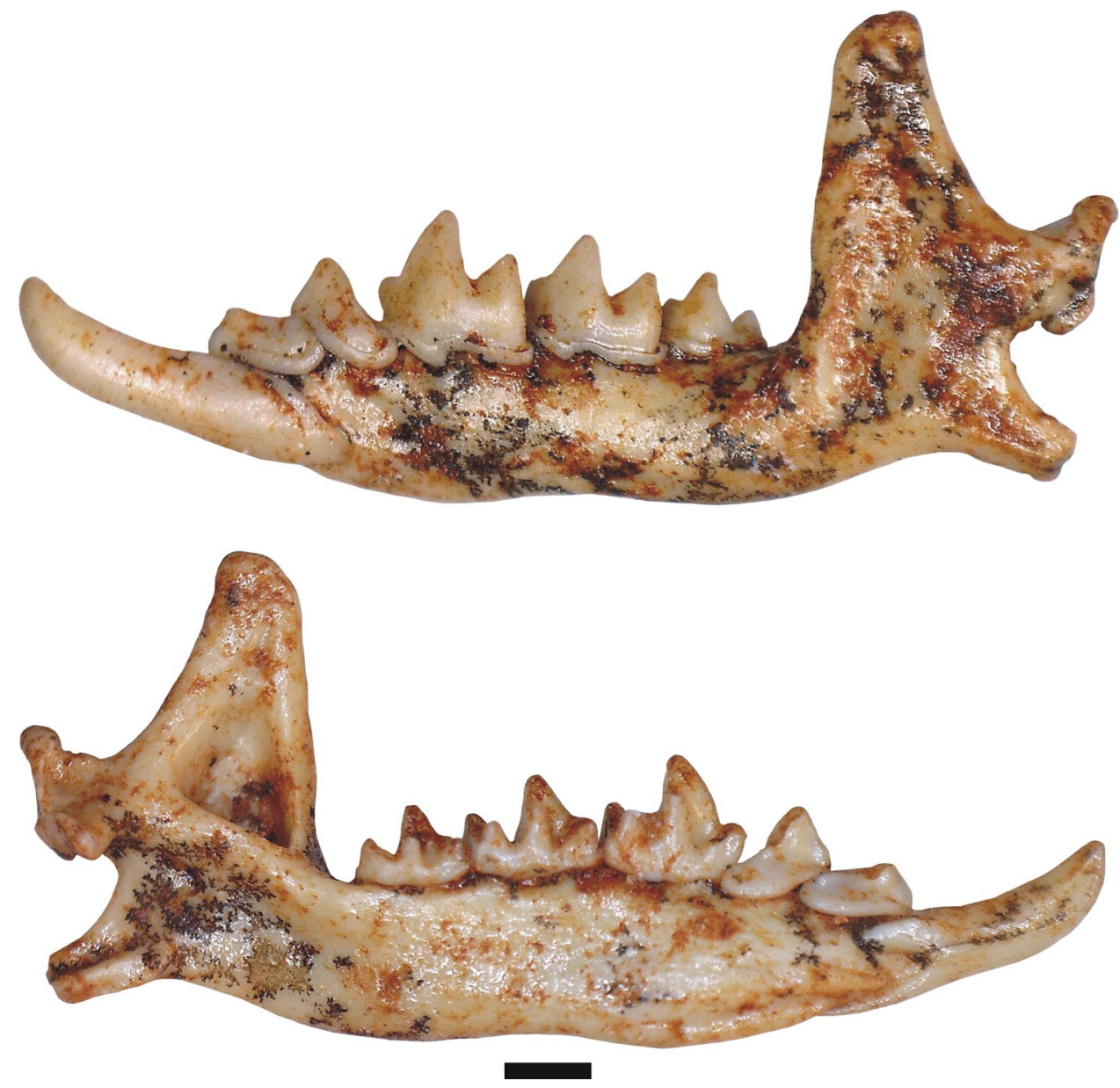

C. suaveolens (Pallas, 1811), C. zimmermanni Wettstein, 1953, and C. sicula Miller, 1901 in its longer first lower antemolar.

Measurements of the neotype. i1-L: 4.35, H: 1.00; a1-L: 1.40, H: 0.66; a2—L: 1.45, H: 0.80; m1-L: 1.66, W: 1.19; m2_L: 1.66, W: 1.08; m3-L: 1.33, W: 0.79.

Description. The coronoid process of the mandible is high; its tip leans strongly backwards. The coronoid spicule is situated high and is distinct. The upper part of the condyle reaches far backwards in buccal view. The condyle is high in posterior view; the interarticular area is long. The internal temporal fossa is large and open, reaching to halfway up the coronoid process. The subfossa is present.

il-The apex is hardly upturned; the dorsal margin is slightly bicuspulate. The buccal cingulum is pronounced. The incisor reaches back further to the posterior end of a1, underneath the anterior half of a 2 .

al-This element is anteroposteriorly quite elongate; only a small part of it is hidden underneath a2. The cingula are well developed on both sides.
a2-The second antemolar is typical for Crocidura; It is high and pointed. The cingula are equally strong on both sides.

$m 1-m 2$ - The lower molars are also typical for Crocidura. The entoconid crest is absent. The buccal cingulum is narrow, but well pronounced; it is undulating in all specimens, but it is less undulate on $\mathrm{m} 2$ than on $\mathrm{m} 1$. The lingual cingulum is weak.

$m 3$ - The talonid of $\mathrm{m} 3$ is reduced to a single cuspid, which is the hypoconid. The development of the cingula is as in $\mathrm{m} 1$ and $\mathrm{m} 2$.

No skull or maxilla is present in the neotype material; however, the upper dentition is usually not used in specific identification of Crocidura species.

Morphometric analysis. It has always been very difficult to determine isolated teeth of genus Crocidura. The significant morphological differences are rather located on their mandibles. In such cases, morphometric analysis may be helpful, but with these statistical methods, morphological observations (on one or more species) can only generally be confirmed or rejected. 

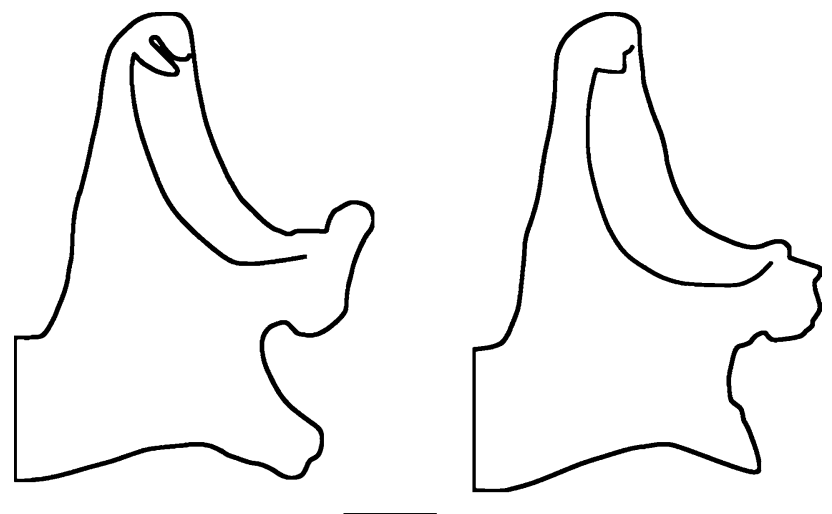

Fig. 3 Difference between the coronoid spicule of Crocidura obtusa (left, neotype, Osztramos 8 locality, HNHM V.73.93.) and Crocidura kornfeldi (right, Somssich Hill 2 locality, HNHM VER 2015. 251.). Scale bar $1 \mathrm{~mm}$. For further comparison see Rzebik-Kowalska (2000: fig. 13)

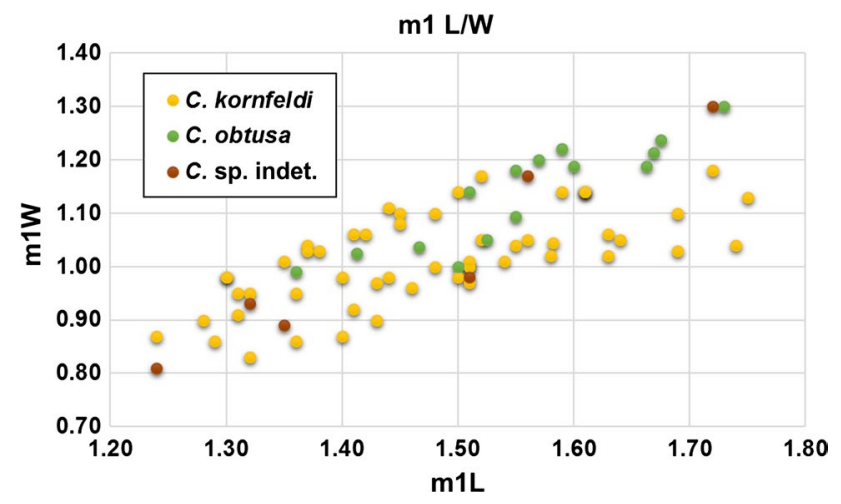

Fig. 4 Scatter plot of measurements of the lower first molars (m1) of the available Crocidura specimens. The measurements of the three taxa overlap, but it is visible that the dimensions of $C$. obtusa are slightly bigger than those of $C$. kornfeldi specimens. Different colors indicate different species, as shown in the legend; yellow $=C$. kornfeldi, green $=C$. obtusa , and brown $=$ Crocidura sp. indet. (kornfeldi or obtusa). For input values see Tables 1,2, 3, and 4

The Early Pleistocene material of the Somssich Hill 2 locality provided a great number of isolated Crocidura teeth. These were very hard to identify, so we made three scatter plots based on the lower molars ( $\mathrm{m} 1, \mathrm{~m} 2$, and $\mathrm{m} 3$ ) (Figs. 4, 5, 6). There were some teeth in situ in the mandibles, which could be certainly determined (C. kornfeldi and C. obtusa from Somssich Hill 2 locality on the scatter plots). All available measurements from literature were collected too (Tables 1, 2, 3, 4). Further mandibles with lower molars were used from the Beremend 16/9, Osztramos 8, and Tarkő sites (Table 3). Unfortunately, the measurements of the studied species almost totally overlap, meaning that they cannot be distinguished based on their measurements only. The average dimensions of the teeth of $C$. obtusa are slightly larger than

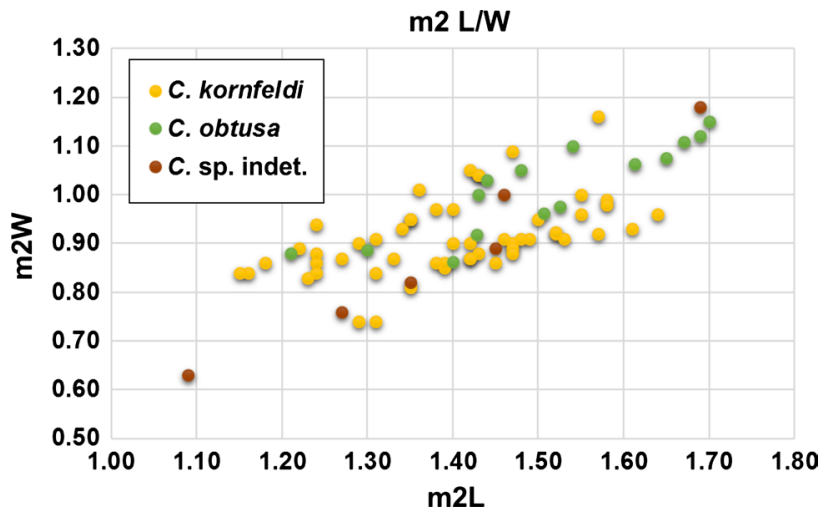

Fig. 5 Scatter plot of measurements of lower second molars (m2) of available Crocidura specimens. The measurements of the three taxa overlap, but it is visible that the dimensions of $C$. obtusa are slightly bigger than those of $C$. kornfeldi specimens. Different colors indicate different species, as shown in the legend; yellow $=C$. kornfeldi, green $=C$. obtusa, and brown $=$ Crocidura sp. indet. (kornfeldi or obtusa). For input values see Tables 1, 2, 3, and 4

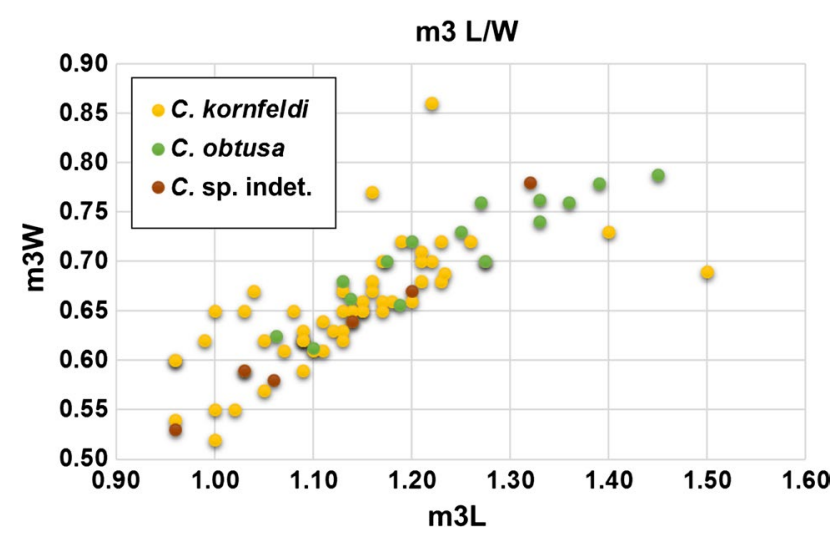

Fig. 6 Scatter plot of measurements of lower third molars (m3) of available Crocidura specimens. The measurements of the three taxa overlap, but it is visible that the dimensions of $C$. obtusa are slightly bigger than those of $C$. kornfeldi specimens. Different colors indicate different species, as shown in the legend; yellow $=C$. kornfeldi, green $=C$. obtusa, and brown=Crocidura sp. indet. (kornfeldi or obtusa). For input values see Tables 1, 2, 3, and 4

those of $C$. kornfeldi, in the case of all teeth by $\sim 0.1 \mathrm{~mm}$, but this is not very significant, and does not allow precise distinction between the two species (Figs. 4, 5, 6).

\section{Discussion}

Kretzoi (1938) mentioned and figured the shape and position of the lower antemolars as differentiating characteristics between C. obtusa and the recent white-toothed shrew species $C$. leucodon and $C$. russula. This distinction (mainly regarding the length of a1) is acceptable for both aforementioned species, and also for C. zimmermanni, C. sicula, and 
Table 1 Input data for scatter plots (Figs. 4, 5, 6) of lower molars of studied Crocidura kornfeldi specimens-1, localities and references (L\&R): A-Plešivec (Fejfar and Horáček 1983), B-Včeláre 3

(Fejfar and Horáček 1983), CVillány 3 (Reumer 1984), DOsztramos 3/2 (Reumer 1984), E-Betfia (Rzebik-Kowalska 2000), F-Marathoussa (Koufos et al. 2001)

\begin{tabular}{|c|c|c|c|c|c|c|}
\hline $\mathrm{L} \& \mathrm{R}$ & $\mathrm{m} 1 \mathrm{~L}$ & $\mathrm{~m} 1 \mathrm{~W}$ & $\mathrm{~m} 2 \mathrm{~L}$ & $\mathrm{~m} 2 \mathrm{~W}$ & $\mathrm{~m} 3 \mathrm{~L}$ & $\mathrm{~m} 3 \mathrm{~W}$ \\
\hline A & 1.32 & 0.83 & 1.16 & 0.84 & 0.96 & 0.60 \\
\hline A & 1.41 & 0.92 & 1.22 & 0.89 & 1.04 & 0.67 \\
\hline A & 1.52 & 1.05 & 1.36 & 1.01 & 1.16 & 0.77 \\
\hline B & 1.24 & 0.87 & 1.15 & 0.84 & 0.96 & 0.60 \\
\hline B & 1.31 & 0.91 & 1.18 & 0.86 & 0.99 & 0.62 \\
\hline B & 1.36 & 0.95 & 1.24 & 0.88 & 1.00 & 0.65 \\
\hline $\mathrm{C}$ & 1.29 & 0.86 & 1.31 & 0.74 & 1.00 & 0.55 \\
\hline $\mathrm{C}$ & 1.51 & 0.97 & 1.43 & 0.88 & 1.11 & 0.64 \\
\hline C & 1.75 & 1.13 & 1.58 & 0.99 & 1.22 & 0.70 \\
\hline D & 1.63 & 1.02 & 1.40 & 0.90 & 1.13 & 0.63 \\
\hline D & 1.69 & 1.03 & 1.49 & 0.91 & 1.15 & 0.65 \\
\hline D & 1.74 & 1.04 & 1.57 & 0.92 & 1.17 & 0.66 \\
\hline E & 1.30 & 0.98 & 1.24 & 0.84 & 0.96 & 0.54 \\
\hline E & 1.38 & 1.03 & 1.31 & 0.91 & 1.10 & 0.61 \\
\hline E & 1.45 & 1.08 & 1.40 & 0.97 & 1.18 & 0.66 \\
\hline E & 1.32 & 0.95 & 1.24 & 0.86 & 1.05 & 0.57 \\
\hline E & 1.37 & 1.04 & 1.29 & 0.90 & 1.14 & 0.64 \\
\hline E & 1.44 & 1.11 & 1.35 & 0.95 & 1.21 & 0.68 \\
\hline E & 1.30 & 0.98 & 1.23 & 0.83 & 1.11 & 0.61 \\
\hline E & 1.42 & 1.06 & 1.35 & 0.95 & 1.15 & 0.66 \\
\hline $\mathrm{E}$ & 1.50 & 1.14 & 1.43 & 1.04 & 1.21 & 0.70 \\
\hline $\mathrm{E}$ & 1.35 & 1.01 & 1.27 & 0.87 & 1.07 & 0.61 \\
\hline E & 1.41 & 1.06 & 1.34 & 0.93 & 1.12 & 0.63 \\
\hline $\mathrm{E}$ & 1.48 & 1.10 & 1.42 & 1.05 & 1.20 & 0.66 \\
\hline $\mathrm{E}$ & 1.37 & 1.03 & 1.31 & 0.84 & 1.09 & 0.62 \\
\hline E & 1.45 & 1.10 & 1.38 & 0.97 & 1.16 & 0.67 \\
\hline E & 1.52 & 1.17 & 1.47 & 1.09 & 1.23 & 0.72 \\
\hline $\mathrm{F}$ & 1.43 & 0.90 & 1.45 & 0.86 & 1.16 & 0.68 \\
\hline $\mathrm{F}$ & 1.54 & 1.01 & 1.47 & 0.90 & 1.17 & 0.70 \\
\hline $\mathrm{F}$ & 1.64 & 1.05 & 1.50 & 0.95 & 1.19 & 0.72 \\
\hline
\end{tabular}

C. suaveolens (Vogel 1988; Vogel et al. 1989). Distinction from Crocidura zorzii by measurements seems feasible.

Several authors distinguished C. obtusa from C. kornfeldi based on different dimensions, while Botka and Mészáros (2015) elaborated a rich Crocidura material containing the remains of both species from the late Early Pleistocene Somssich Hill 2 locality, finding that the measurements of molars of the two forms largely overlap. The morphometric investigations of the recent studies supported the hypothesis that distinction of the two species by measurements is not realistic (Figs. 4, 5, 6).

Morphological study of the mandible is essential for correct taxonomic determination. The two Early Pleistocene Crocidura species can be distinguished morphologically mainly by the characteristics of the coronoid process. The tip of the coronoid process of $C$. obtusa leans more backwards than that of $C$. kornfeldi. The process of the upper margin of the external temporal fossa (the coronoid spicule) is distinct in C. obtusa but indistinct in C. kornfeldi (Fig. 3). The morphological difference between the coronoid processes could be suggestive of different feeding habits of the two white-toothed shrews.

Considering the above-mentioned reasons, we offer the taxonomic name Crocidura sp. (kornfeldi-obtusa group) as the most correct classification for researchers elaborating only isolated teeth remains of these forms.

\section{Conclusions}

Purpose of clarifying the taxonomic status-The holotype was lost, and the original description was incomplete.

Main specific morphological characters-Distinct coronoid spicule and long first antemolar.

Crocidura obtusa Kretzoi, 1938-Differs from (A) C. kornfeldi Kormos, 1934 in having higher ramus mandibulae, distinct coronoid spicule, tip of the coronoid process leaning more backwards, higher condyle, and longer 
Table 2 Input data for scatter plots (Figs. 4, 5, 6) of lower molars of studied Crocidura kornfeldi specimens-2, localities and references (L\&R): A-Sima del Elefante (Rofes and Cuenca-Bescós 2011), B-Somssich Hill 2 (Botka and Mészáros 2015), C-Beremend 14 (Pazonyi et al. 2016)
Table 3 Input data for scatter plots (Figs. 4, 5, 6) of lower molars of studied Crocidura obtusa specimens, localities and references (L\&R): A-Betfia IX (cf., Rzebik-Kowalska 2000), B-Somssich Hill 2 (Botka and Mészáros 2015), C-Beremend $16 / 9$, (cf., this paper), DOsztramos 8 (this paper), ETarkő (this paper)

\begin{tabular}{lllllll}
\hline $\mathrm{L} \& \mathrm{R}$ & $\mathrm{m} 1 \mathrm{~L}$ & $\mathrm{~m} 1 \mathrm{~W}$ & $\mathrm{~m} 2 \mathrm{~L}$ & $\mathrm{~m} 2 \mathrm{~W}$ & $\mathrm{~m} 3 \mathrm{~L}$ & $\mathrm{~m} 3 \mathrm{~W}$ \\
\hline $\mathrm{A}$ & 1.46 & 0.96 & 1.39 & 0.85 & 1.09 & 0.59 \\
$\mathrm{~A}$ & 1.51 & 1.00 & 1.48 & 0.91 & 1.17 & 0.65 \\
$\mathrm{~A}$ & 1.55 & 1.04 & 1.55 & 0.96 & 1.26 & 0.72 \\
$\mathrm{~A}$ & 1.28 & 0.90 & 1.35 & 0.81 & 1.02 & 0.55 \\
$\mathrm{~A}$ & 1.51 & 1.00 & 1.46 & 0.91 & 1.13 & 0.65 \\
$\mathrm{~A}$ & 1.69 & 1.10 & 1.58 & 0.98 & 1.22 & 0.86 \\
$\mathrm{~A}$ & 1.36 & 0.86 & 1.29 & 0.74 & 1.00 & 0.52 \\
$\mathrm{~A}$ & 1.44 & 0.98 & 1.42 & 0.87 & 1.09 & 0.62 \\
$\mathrm{~A}$ & 1.59 & 1.14 & 1.55 & 1.00 & 1.50 & 0.69 \\
$\mathrm{~A}$ & 1.31 & 0.95 & 1.33 & 0.87 & 1.03 & 0.59 \\
$\mathrm{~A}$ & 1.48 & 1.00 & 1.42 & 0.90 & 1.09 & 0.63 \\
$\mathrm{~A}$ & 1.63 & 1.06 & 1.53 & 0.91 & 1.14 & 0.65 \\
$\mathrm{~A}$ & 1.43 & 0.97 & 1.42 & 0.87 & 1.05 & 0.62 \\
$\mathrm{~A}$ & 1.51 & 1.01 & 1.47 & 0.89 & 1.09 & 0.62 \\
$\mathrm{~A}$ & 1.56 & 1.05 & 1.52 & 0.92 & 1.13 & 0.62 \\
$\mathrm{~A}$ & 1.40 & 0.87 & 1.39 & 0.86 & 1.08 & 0.65 \\
$\mathrm{~A}$ & 1.50 & 0.98 & 1.47 & 0.88 & 1.13 & 0.67 \\
$\mathrm{~A}$ & 1.58 & 1.02 & 1.61 & 0.93 & 1.21 & 0.71 \\
$\mathrm{~B}$ & 1.61 & 1.14 & 1.24 & 0.94 & 1.03 & 0.65 \\
$\mathrm{~B}$ & 1.61 & 1.14 & 1.43 & 1.04 & 1.23 & 0.68 \\
$\mathrm{~B}$ & 1.61 & 1.14 & 1.57 & 1.16 & 1.40 & 0.73 \\
$\mathrm{C}$ & 1.40 & 0.98 & 1.38 & 0.86 & 1.15 & 0.65 \\
$\mathrm{C}$ & 1.58 & 1.04 & 1.52 & 0.92 & 1.23 & 0.69 \\
$\mathrm{C}$ & 1.72 & 1.18 & 1.64 & 0.96 & 1.28 & 0.70 \\
\hline & & & & & & \\
\hline
\end{tabular}

\begin{tabular}{lllllll}
\hline $\mathrm{L} \& \mathrm{R}$ & $\mathrm{m} 1 \mathrm{~L}$ & $\mathrm{~m} 1 \mathrm{~W}$ & $\mathrm{~m} 2 \mathrm{~L}$ & $\mathrm{~m} 2 \mathrm{~W}$ & $\mathrm{~m} 3 \mathrm{~L}$ & $\mathrm{~m} 3 \mathrm{~W}$ \\
\hline $\mathrm{A}$ & 1.55 & 1.18 & 1.44 & 1.03 & 1.25 & 0.73 \\
$\mathrm{~A}$ & 1.57 & 1.20 & 1.48 & 1.05 & 1.33 & 0.74 \\
$\mathrm{~A}$ & 1.59 & 1.22 & 1.54 & 1.10 & 1.36 & 0.76 \\
$\mathrm{~B}$ & 1.36 & 0.99 & 1.21 & 0.88 & 1.13 & 0.68 \\
$\mathrm{~B}$ & 1.51 & 1.14 & 1.43 & 1.00 & 1.20 & 0.72 \\
$\mathrm{~B}$ & 1.73 & 1.30 & 1.69 & 1.12 & 1.27 & 0.76 \\
$\mathrm{C}$ & 1.41 & 1.03 & 1.30 & 0.89 & 1.06 & 0.63 \\
$\mathrm{C}$ & 1.47 & 1.04 & 1.43 & 0.92 & 1.14 & 0.66 \\
$\mathrm{C}$ & 1.53 & 1.05 & 1.53 & 0.98 & 1.18 & 0.70 \\
$\mathrm{D}$ & 1.66 & 1.19 & 1.65 & 1.08 & 1.33 & 0.76 \\
$\mathrm{D}$ & 1.67 & 1.21 & 1.67 & 1.11 & 1.39 & 0.78 \\
$\mathrm{D}$ & 1.68 & 1.24 & 1.70 & 1.15 & 1.45 & 0.79 \\
$\mathrm{E}$ & 1.50 & 1.00 & 1.40 & 0.86 & 1.10 & 0.61 \\
$\mathrm{E}$ & 1.55 & 1.09 & 1.51 & 0.96 & 1.19 & 0.66 \\
$\mathrm{E}$ & 1.60 & 1.19 & 1.61 & 1.06 & 1.28 & 0.70 \\
\hline
\end{tabular}

interarticular area, from (B) Crocidura zorzii Pasa, 1942 in its smaller dimensions, and from (C) C. leucodon (Hermann, 1780), C. russula (Hermann, 1780), C. suaveolens (Pallas, 1811), C. zimmermanni Wettstein, 1953, and C. sicula Miller, 1901 in its longer first lower antemolar.
Reasons for believing the name-bearing type is lost-The collection where the type material was housed has been partially destroyed. We could not find it in either Hungarian or possible foreign collections. This procedure is discussed in detail in "Historical background" section. 
Table 4 Input data for scatter plots (Figs. 4, 5, 6) of lower molars of studied Crocidura sp. indet. specimens, localities and references (L\&R): AAlmenara-Casablanca 3 (Furió et al. 2007), B-Somssich Hill 2 (Botka and Mészáros 2015)

\begin{tabular}{lllllll}
\hline $\mathrm{L} \& \mathrm{R}$ & $\mathrm{m} 1 \mathrm{~L}$ & $\mathrm{~m} 1 \mathrm{~W}$ & $\mathrm{~m} 2 \mathrm{~L}$ & $\mathrm{~m} 2 \mathrm{~W}$ & $\mathrm{~m} 3 \mathrm{~L}$ & $\mathrm{~m} 3 \mathrm{~W}$ \\
\hline $\mathrm{A}$ & 1.24 & 0.81 & 1.27 & 0.76 & 0.96 & 0.53 \\
$\mathrm{~A}$ & 1.35 & 0.89 & 1.35 & 0.82 & 1.06 & 0.58 \\
$\mathrm{~A}$ & 1.51 & 0.98 & 1.45 & 0.89 & 1.14 & 0.64 \\
$\mathrm{~B}$ & 1.32 & 0.93 & 1.09 & 0.63 & 1.03 & 0.59 \\
$\mathrm{~B}$ & 1.56 & 1.17 & 1.46 & 1.00 & 1.20 & 0.67 \\
$\mathrm{~B}$ & 1.72 & 1.30 & 1.69 & 1.18 & 1.32 & 0.78 \\
\hline
\end{tabular}

Evidence that the neotype is consistent with the former name-bearing type-Due to the incomplete description and figures given by Kretzoi (1938), the neotype specimen cannot be clearly identified with the form described by him. However, some facts suggest that they belong to the same species.

Several Early Pleistocene Crocidura specimens, identified as $C$. obtusa, have been reported since the publication of the original description. These shrews were clearly distinguishable from the contemporary C. kornfeldi Kormos, 1934 and C. zorzii Pasa, 1942, although they seem to belong to the same species as the neotype shown in the present paper. This proves that a third white-toothed shrew species was also living at that time. The most likely hypothesis is that Kretzoi discovered this species as well and described it as C. obtusa.

Evidence that the neotype came as nearly as practicable from the original type locality and geological horizonThere is no appropriate specimen from the Gombasek record. The Osztramos 8 site is geographically and stratigraphically the nearest locality at which C. obtusa shrews occurred (see "Historical background" section).

Acknowledgements Open access funding provided by Hungarian Natural History Museum (MTM). We thank Jan Wagner for advice about possible type specimens and for information on Gombasek material stored in Slovakia and the Czech Republic, and Ursula Göhlich and Lars Werdelin for valuable suggestions regarding this publication. We are very grateful to the reviewers of our manuscript, Irina Ruf (Assoc. Editor) and Mike Reich (Editor-in-Chief), and especially Lutz Maul and Lars van den Hoek Ostende for comments and very useful and valuable suggestions. The Hungarian Scientific Research Fund (OTKA K104506 project) supported this work.

Open Access This article is distributed under the terms of the Creative Commons Attribution 4.0 International License (http://creativeco mmons.org/licenses/by/4.0/), which permits unrestricted use, distribution, and reproduction in any medium, provided you give appropriate credit to the original author(s) and the source, provide a link to the Creative Commons license, and indicate if changes were made.

\section{References}

Boda, J. 1964. Magyarországi ösmaradványtípusok jegyzéke. Catalogus originalium fossilium Hungariae. Budapest: Magyar Állami Földtani Intézet. (in Hungarian).
Botka, D., and L. Mészáros. 2014. Beremendia (Mammalia, Soricidae) remains from the late Early Pleistocene Somssich Hill 2 locality (Southern Hungary) and their taxonomic, biostratigraphical, palaeoecological, and palaeobiogeographical relations. Fragmenta Palaeontologica Hungarica 31: 83-115.

Botka, D., and L. Mészáros. 2015. Crocidura (Mammalia, Soricidae) remains from the late Early Pleistocene Somssich Hill 2 locality (Villány Hills, Southern Hungary). Fragmenta Palaeontologica Hungarica 32: 67-98.

Fejfar, O., and I. Horáček. 1983. Zur Entwicklung der Kleinsäugerfaunen im Villányium und Alt-Biharium auf dem Gebiet der ČSSR. Schriftenreihe für Geologische Wissenschaften 19/20: 111-207.

Fischer von Waldheim, G. 1814. Zoognosia tabulis synopticis illustrata, in usum praelectionum Academia Imperialis Medico-Chirurgica Mosquensis. 3: Quadrupedum reliquorum, Cetorum et Monotrymatum descriptionem continens, 1-694. Mosquæ [Moscow]: N.S. Vsevolozsky.

Furió, M., A. Santos-Cubedo, R. Minwer-Barakat, and J. Agustí. 2007. Evolutionary history of the African soricid Myosorex (Insectivora, Mammalia) out of Africa. Journal of Vertebrate Paleontology 27(4): 1018-1032.

Gasparik, M. 2007. "Elephants" in the cellar. A revision of the Neogene Proboscidean remains, damaged in the fire of the Hungarian Natural History Museum in 1956. Fragmenta Palaeontologica Hungarica 24/25: 83-91.

Hermann, J. 1780. "310) Die gemeine Spitzmaus” and "311) Der Weißzahn”. In Geographische Geschichte des Menschen, und der vierfüssigen Thiere, 2: Enthält ein vollständiges Verzeichniß aller bekannten Quadrupeden, ed. E.A.W. von Zimmermann, 382. Leipzig: Weygand.

Jánossy, D. 1962. Vorläufige Mitteilung über die Mittelpleistozäne Vertebratenfauna der Tarkő-Felsnische (NO-Ungarn, BükkGebirge). Annales historico-naturales Musei nationalis hungarici 54: $155-176$.

Jánossy, D. 1969a. Stratigraphische Auswertung der europäischen mittelpleistozänen Wirbeltierfauna. Teile II. Berichte der Deutschen Gesellschaft für Geologische Wissenschaften (A: Geologie und Paläontologie) 14(4-5): 367-438.

Jánossy, D. 1969b. Stratigraphische Auswertung der europäischen mittelpleistozänen Wirbeltierfauna. Teile II. Berichte der Deutschen Gesellschaft für Geologische Wissenschaften (A: Geologie und Paläontologie) 14(4-5): 573-643.

Jánossy, D. 1986. Pleistocene vertebrate faunas of Hungary. Budapest: Akadémiai Kiadó.

Jánossy, D. 1996. Lower Pleistocene vertebrate faunas from the localities 16 and 17 of Beremend (Southern Hungary). Fragmenta Mineralogica et Palaeontologica 18: 91-102.

Jánossy, D., and L. Kordos. 1977. Az Osztramos gerinces lelőhelyeinek faunisztikai és karsztmorfológiai áttekintése (1975-ig). [Faunistical and karstmorphological review of palaeontological localities for vertebrates at Osztramos (Northern 
Hungary)]. Fragmenta Mineralogica et Palaeontologica 8: 39-72. (in Hungarian).

Koenigswald, W. von. 1971. Die altpleistozäne Wirbeltierfaunula aus der Spaltenfüllung Weissenburg 7 (Bayern). Mitteilungen der Bayerischen Staatssammlung für Paläontologie und Historische Geologie 11: 117-122.

Kormos, T. 1934. Neue Insektenfresser, Fledermäuse und Nager aus dem Oberpliozän der Villányer Gegend. Földtani Közlöny 64: 296-321.

Koufos, G.D., K.V. Vassiliadou, K.K. Koliadimou, and G.E. Syrides. 2001. Early Pleistocene small mammals from Marathoussa, a new locality in the Mygdonia basin, Macedonia, Greece. Deinsea 8: 49-102.

Kretzoi, M. 1938. Die Raubtiere von Gombaszög nebst einer übersicht der Gesamtfauna (Ein Beitrag zur Stratigraphie des Altquartaers). Annales historico-naturales Musei nationalis hungarici 31: 88-157.

Kretzoi, M. 1941. Weitere Beiträge zur Kenntnis der Fauna von Gombaszög. Annales historico-naturales Musei nationalis hungarici 34: 105-139.

Kretzoi, M. 1956. Die Altpleistozänen Wirbeltierfaunen des Villányer Gebirges. Geologica Hungarica, Series Palaeontologica 27: $1-264$.

Linnaeus, C. 1758. Systema Naturae per Regna Tria Naturae, Secundum Classes, Ordines, Genera, Species, cum Characteribus, Differentiis, Synonymis, Locis. Volume 1: Regnum Animale. Editio decima, reformata. Stockholm: Laurentii Salvii.

Miller, G.S. 1901. Five shrews from Europe. Proceedings of the Biological Society of Washington 14: 41-45.

Milne-Edwards, H., and A. Milne-Edwards. 1874. Recherches pour servir à l'histoire naturelle des mammifères, comprenant des considérations sur la classification de ces animaux. Paris: Masson.

Pálfy, J., A. Dulai, M. Gasparik, P. Ozsvárt, P. Pazonyi, and O. Szives. 2008. Catalogue of invertebrate and vertebrate paleontological type specimens of the Hungarian Natural History Museum. Budapest: Hungarian Natural History Museum.

Pallas, P.S. 1811. Zoographia Rosso-Asiatica: sistens omnium animalium in extenso Imperio Rossico et adiacentibus maribus observatorum recensionem, domicilia, mores et descriptiones anatomen atque icones plurimorum. Volume 1. Officina Caes. Petropolis: Academiae Scientiarum Impress.

Papp, G. 2016. The Hungarian Natural History Museum and the Hungarian Revolution of 1956. Fire in the building of the National Museum. Annales historico-naturales Musei nationalis hungarici 108: 196-215.

Pasa, A. 1942. I depositi ossiferi di Soave nel Veronese. Atti della Reale Accademia di Agricoltura, Scienze e Lettre di Verona (Serie 5) 20: 37-50.

Pazonyi, P. 2011. Palaeoecology of Late Pliocene and Quaternary mammalian communities in the Carpathian Basin. Acta Zoologica Cracoviensia 54A(1-2): 1-29.
Pazonyi, P., L. Mészáros, J. Hír, and Z. Szentesi. 2016. The lowermost Pleistocene rodent and soricid (Mammalia) fauna from Beremend 14 locality (South Hungary) and its biostratigraphical and palaeoecological implications. Fragmenta Palaeontologica Hungarica 33: 99-134

Reumer, J.W.F. 1984. Ruscinian and early Pleistocene Soricidae (Insectivora, Mammalia) from Tegelen (The Netherlands) and Hungary. Scripta Geologica 73: 1-173.

Rofes, J., and G. Cuenca-Bescós. 2011. Evolutionary history and biogeography of the genus Crocidura (Mammalia, Soricidae) in Europe, with emphasis on Crocidura kornfeldi. Mammalian Biology 76(1): 64-78.

Rzebik-Kowalska, B. 2000. Insectivora (Mammalia) from the Early and early Middle Pleistocene of Betfia in Romania. I. Soricidae Fischer von Waldheim, 1817. Acta Zoologica Cracoviensia 43 (1-2): 1-53.

Rzebik-Kowalska, B. 2002. The Pliocene and Early Pleistocene Lipotyphla (Insectivora, Mammalia) from Romania. Acta Zoologica Cracoviensia 45(2): 251-281.

Rzebik-Kowalska, B. 2013. Sorex bifidus n. sp. and the rich insectivore mammal fauna (Erinaceomorpha, Soricomorpha, Mammalia) from the Early Pleistocene of Żabia Cave in Poland. Palaeontologia Electronica 16(2/12A): 1-35.

Stefaniak, K., A. Tyc, and P. Socha (eds.). 2009. Karst of the Czestochowa Upland and of the Eastern Sudetes: palaeoenvironments and protection. Wroclaw: Studies of the Faculty of Earth Sciences University of Silesia.

Vogel, P. 1988. Taxonomical and biogeographical problems in Mediterranean shrews of the genus Crocidura (Mammalia, Insectivora) with reference to a new karyotype from Sicily (Italy). Bulletin de la Société vaudoise des sciences naturelles 79: 37-48.

Vogel, P., R. Hutterer, and M. Sarà. 1989. The correct name, species diagnosis and distribution of the Sicilian shrew. Bonner Zoologische Beiträge 40(3-4): 243-248.

Waddell, P.J., N. Okada, and M. Hasegawa. 1999. Towards resolving the interordinal relationships of placental mammals. Systematic Biology 48(1): 1-5.

Wagler, J.G. 1832. Mittheilungen über einige merkwürdige Thiere. Encyclopädische Zeitung 25: 275-281.

Wagner, J., and M. Gasparik. 2014. Research history of Pleistocene faunas in Gombasek quarry (Slovakia), with comments to the type specimen and the type locality of Ursus deningeri gombaszogensis Kretzoi, 1938. Fragmenta Palaeontologica Hungarica 31: 125-143.

Wettstein, O. 1953. Die Insectivora von Kreta. Mammalian Biology 17: 4-13. 